\title{
Restoration and Conservation of Deteriorated Arid Land by a Native Thorny Shrub Lycium shawii
}

\author{
Modi Mohammed Ahmed and Ali Mohammed Al-Dousari \\ Crisis Decision Program, Environment and Life Science Research Center, Kuwait Institute for Scientific Research, P.O. Box 24885, \\ Safat 13109, Kuwait
}

\begin{abstract}
Land degradation is of great concern in the desert environment of Kuwait, as it has a negative impact on the natural resources. In response to this situation, Kuwait conserves their natural environment by setting aside areas of significant natural ecosystem, such as wild life center at the Liyah area. The area suffered during the past four decades from severe environmental pressures due to the excessive exploitation of natural resources of sand and gravel as well as overgrazing and military activities. Re-vegetation and restoration programs were applied in the degraded areas in Liyah in December 2003. A large variety of native plants were used for the restoration, however, in this research, only one native perennial drought resistant plant Lycium shawii (Awsaj) was highlighted. Tissue cultured thorny shrub planted at experimental site showed high adaptation on gravel hill side with harsh field condition. Their survival rate was $100 \%$ under drip irrigation only $10 \%$ was the mortality rate due to improper fixation of irrigation system. The average length of the main stem and the number of branches gradually increased by year from $42 \mathrm{~cm}$ with three branches in 2011 to $170 \mathrm{~cm}$ with seven branches in 2014. Since Lycium shrubs have the ability to grow in severely degraded areas, with extreme condition of prolonged drought, high temperature and poor nutrient soil as well as their ability to form nabkha, it is considered to be most suitable shrub used for rehabilitation program at Liyah area.
\end{abstract}

Key words: Degraded lands, restoration program, thorny shrub, Lycium shawii.

\section{Introduction}

The area of Liyah is about $199.89 \mathrm{~km}^{2}$, occupying $1.12 \%$ of total area of Kuwait. The terrain is almost flat interrupted with group of hills, dry valleys and depressions. The area is rich with aeolian deposits and gravel deposits, which were the direct causes for the start of gravel extraction activities in early sixties [1]. The Council of Ministers referred to Supreme Council of Environment in December 2015 that northern part of Liyah area is designated to be a center for development of wild life habitats.

Harsh climate and other human activities make the desert plants difficult to survive. The loss of Kuwait's desert flora has prompted the need to conserve and protect plants in the wild and has led to the establishment of preserved area. These areas remain the best and cheapest way of ensuring long-term

Corresponding author: Modi Mohammed Ahmed, M.Sc., research field: desert rehabilitation. survival of wild life, hence, to conserve plants effectively, so their habitats must be conserved.

Field surveys in Kuwait confirmed that vegetation cover plays an important role in controlling land degradation. In Kuwait, native drought resistant plants are highly tailored to the adverse environmental conditions, such as extreme temperature, salinity and drought $[2,3]$. Examples of different perennial plant species are Haloxylon salicornicum, Cyperus conglomerates, Rhanterium epapposum, Astragallus spinosus, Citrullus colocynthis, Halocnemum strobilaceu, Salicornia europaea, Tamarix aucheriana, Lycium shawii and Nitraria retusa.

Lycium shawii is a perennial drought desert plant. It is rigid shiny shrub up to $3 \mathrm{~m}$ high, stem straight with spiny branched. Their leaves are thin, elliptical shape on short stalk, flowers are solitary, small with variable color white, pink to purple, fruits are berries edible and contain many seeds [4]. The best flowering time 

Thorny Shrub Lycium shawii

is September to April [5]. It is common in Kuwait desert in variety of habitats: gravel plains, hillsides, valleys, sandy stone ridges and along drainage basin, such as valleys and depressions [6]. It is widely used as windbreaks and stabilizer. Their stems boiled in water with the strained liquid are used as laxative and diuretic, leaves used to treat jaundice in Saudi Arabia and their berries fruits are edible, used to treat colic, and also applied around the eyes to improve vision [4].

Lycium plant was selected to be cultivated in the study area due to ability to tolerate extreme adverse conditions and ability to form large nabkha used as sand protector from wind and water erosion as well as animal shelter. The study aimed to test and monitor the effectiveness and technical aspects of using Lycium shawii for restoration program in degraded lands at Liyah refilled quarries by detailed field surveys.

\section{Methodology}

The study area is located at Liyah desert northern part of country. The experimental site lied on degraded gravel hill side along the slip face about 100 $\mathrm{m}^{2}$ areas. The soil is compacted, rich with sand and gravel (Fig. 1). The top soil is eroded by wind.
Healthy seedlings of Lycium shawii were propagated in large number via tissue culture method. Plant materials of Lycium shawii (Aswaj) were collected from the open desert of Kuwait for the in vitro study. Shoot meristem cultures and axillary bud cultures of such plants were initiated using the standard culture method. Cultures were isolated and multiplied through somatic embryogenesis and organogenesis methods of multiplication. Then, rooted plantlets were removed from the culture tubes and washed in running tap water and soap to remove the media and kept inside water for $2 \mathrm{~h}$. Later, cleaned plantlets were treated with $0.5 \%$ Benlate ${ }^{\circledR}$ fungicide solution and planted in sterile soil mix prepared by mixing sand, peat moss and humus at a 1:1:1 ratio and autoclaved at $121{ }^{\circ} \mathrm{C}$ for $45 \mathrm{~min}$. These plantlets were reserved inside the transparent containers and kept inside the growth room under closed conditions. After one week, the plantlets were transferred to the greenhouse and gradually exposed to the greenhouse environmental conditions [7].

These seedlings were transported to the green house environment for adaptation and then to the open field conditions to increase gradually the toughness before planting in the desert. About 500 plant pits of $30 \mathrm{~cm} \times 30 \mathrm{~cm}$ size were prepared using drilling machine,

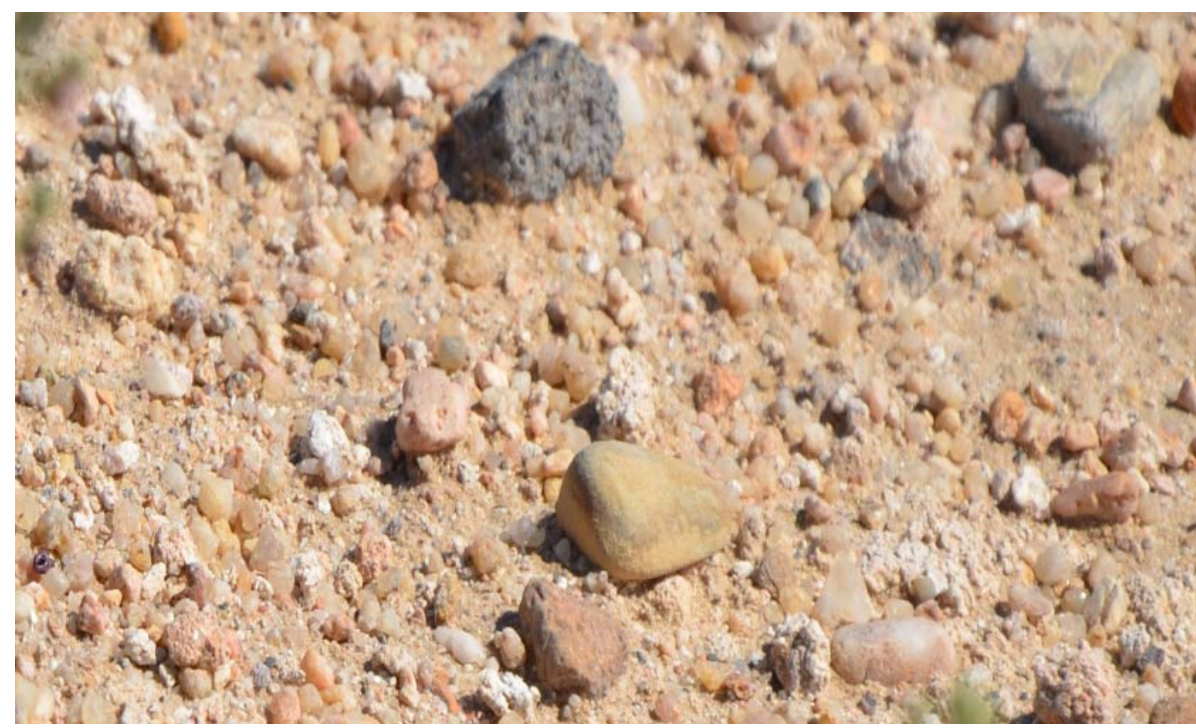

Fig. 1 The soil of pilot area rich with coarse sand and gravel. 
because the soil was very hard. Such small pit was filled with peat moss and compost and covered with date palm leaves, then seedlings carefully planted inside the pit, immediately well irrigated with fresh water about 4-5 $\mathrm{L}$ and the second day until one week irrigated with $3 \mathrm{~L}$. The distance between individual plants was $2 \mathrm{~m}$. All plantlets at first years are irrigated with drip irrigation with fresh water for $2 \mathrm{~L}$ once in 3 $\mathrm{d}$ during spring and daily during summer season at $1 \mathrm{~h}$ duration per day. At the second year, the plantlets start to irrigate with brackish water about $2 \mathrm{~L}$ once in $3 \mathrm{~d}$ during spring and $4 \mathrm{~d}$ during summer season. At the third year, the amount of irrigation reduces to $1 \mathrm{~L}$ once in $2 \mathrm{~d}$ in spring and $3 \mathrm{~d}$ during summer season. At the fourth year, the hardiness of plantlets is well suited for tolerance against hot summer sand storm. Therefore, plantlets are irrigated with $1 \mathrm{~L}$ once in $2 \mathrm{~d}$ in summer season and $3 \mathrm{~d}$ in spring. Water is drawn from a productive well, which was established near planting site and produced brackish water their salinity about $4,900 \mathrm{mg} / \mathrm{L}$ of total dissolved solids (TDS). The morphological characteristics for 200 Lycium seedlings were measured every six months from 2011 to 2014 (Fig. 2). Moreover, the morphological parameters for 20 nabkha of Lycium plants distributed in desert of Kuwait were measured.

Several preliminary fundamental measurements were carried out at the pilot site, such as soil moisture, infiltration, bulk density, porosity, $\mathrm{pH}$ and electrical conductivity. Site information is determined through field examination, soil sampling and their analysis in the laboratory. A total of 25 soil samples were collected at depth of $0-20 \mathrm{~cm}$. On site investigation including soil moisture is determined using gravimetric method [8]. The bulk density is measured using standard core method, and calculation of percent pore space is used to determine porosity percentage. To determine electrical conductivity and $\mathrm{pH}$ of the soil sample, a portion of soil was used to prepare. The $\mathrm{pH}$ was measured after saturated soil paste prepared by a calibrated $\mathrm{pH}$ meter ( $\mathrm{pH} 4$ and 9). After measuring the soil $\mathrm{pH}$, the saturated paste was transferred to the Buchner funnels connected to the vacuum apparatus and soil saturation extract was collected in collecting vials. Such extract was determined using electrical conductivity meter and the values reported in $\mu \mathrm{S} / \mathrm{cm}$.

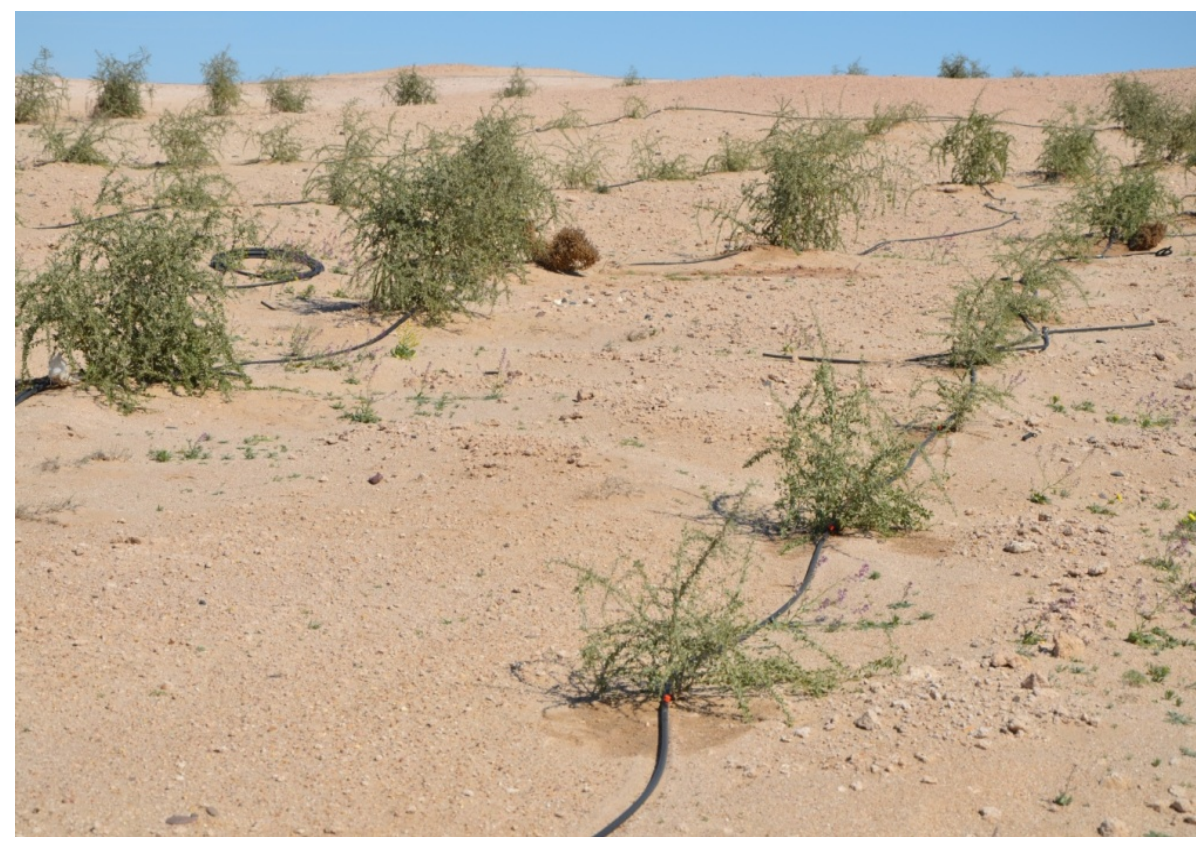

Fig. 2 Lycium shawii planted at experimental site. 


\section{Results and Discussion}

Before plantation, several physical and chemical measurements were recorded for highly degraded experimental site. The soil was alkaline, having $\mathrm{pH}$ values between 7.2-7.9, low electrical conductivity from $2.4 \mu \mathrm{S} / \mathrm{cm}$ to $3 \mu \mathrm{S} / \mathrm{cm}$, high bulk density more than $2 \mathrm{~g} / \mathrm{cm}^{3}$, low porosity (27\%) and high penetration force about $200 \mathrm{psi}$.

The first field trial was carried out during January 2011. The average length of Lycium seedlings was 42 $\mathrm{cm}$ with three branches. All plantlets survived and started to grow after one month of planting. There are no native plants introduced in field. All plantlets survived face strong dust storms and severe sand encroachment. Then at the beginning of spring time, all seedlings flourished and started to sprout and flower. After a year of planting, such seedlings become tolerance against the harsh environmental conditions, produced multiple branches and their stem length increased. For example, at the time of plantation, the average length of the main stem and number of branches was $42 \mathrm{~cm}$ and three branches, respectively, but after one year increased to double, stem length become $104 \mathrm{~cm}$ with five branches. The growth rate was gradually increased for the second, third and fourth year (Table 1, Figs. 3 and 4). The depth of vertical root was only $50 \mathrm{~cm}$ due to hardness soil, and the extension of horizontal root was between $100 \mathrm{~cm}$ to $150 \mathrm{~cm}$ due to availability of soil moisture content. Such tissue cultured thorny shrub showed highly adaptation on gravel hill side with harsh field condition. Their survival rate was $100 \%$; only $10 \%$ of the mortality rate was due to improper fixation of irrigation system, therefore regular examination of the drippers is needed to clear the dust or salt blocks.

Table 1 The average length of the main stem and number of branches of Lycium shawii for the period from 2011 to 2014.

\begin{tabular}{lll}
\hline Date & Average length of the main stem $(\mathrm{cm})$ & Average number of branches \\
\hline April 2011 & 42 & 3 \\
March 2012 & 104 & 5 \\
November 2012 & 113 & 6 \\
April 2013 & 135 & 8 \\
October 2013 & 147 & 10 \\
May 2014 & 160 & 7 \\
December 2014 & 170 & 7 \\
\hline
\end{tabular}

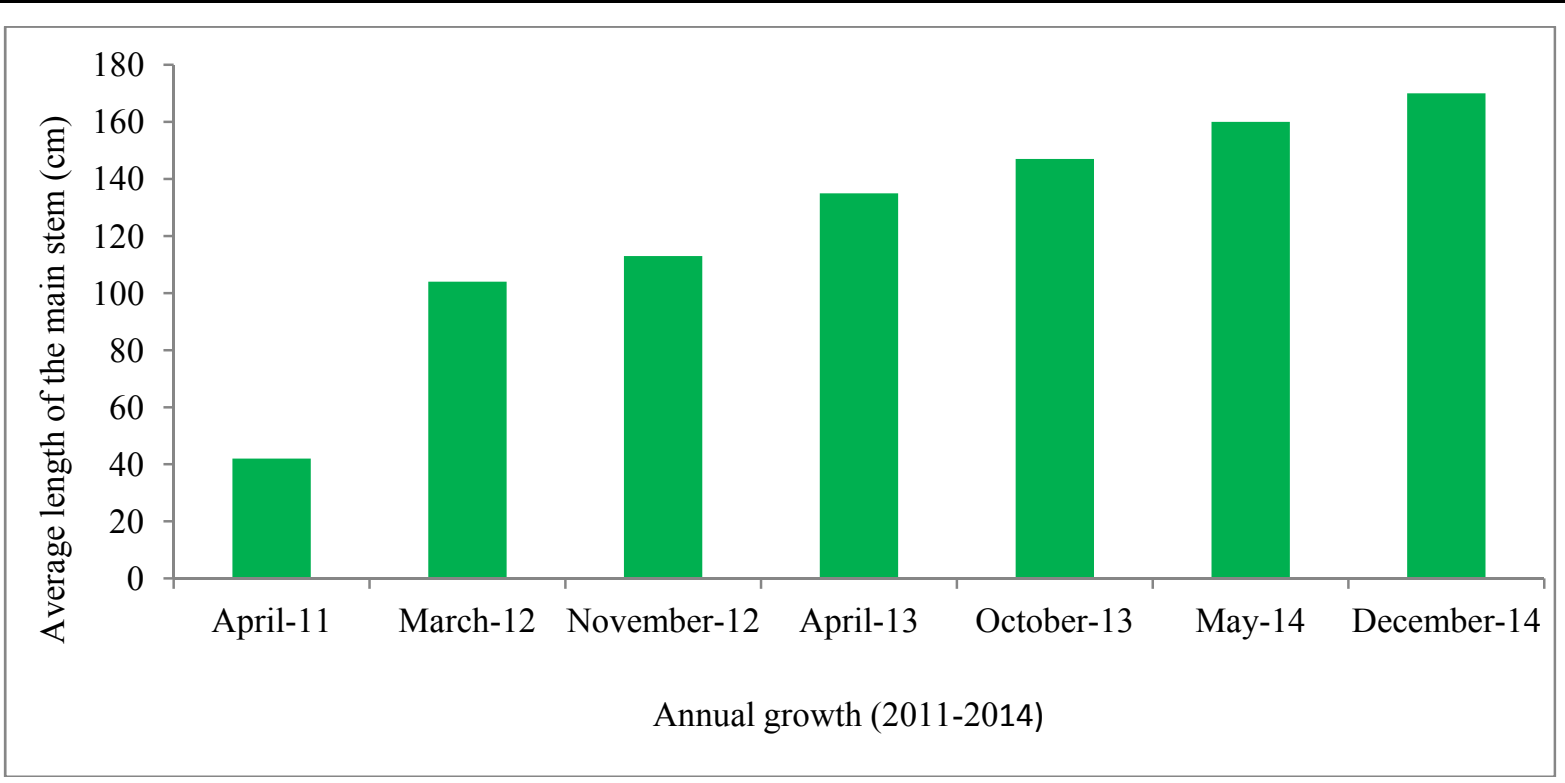

Fig. 3 The average length of the main stem of Lycium shawii for the period from 2011 to 2014. 


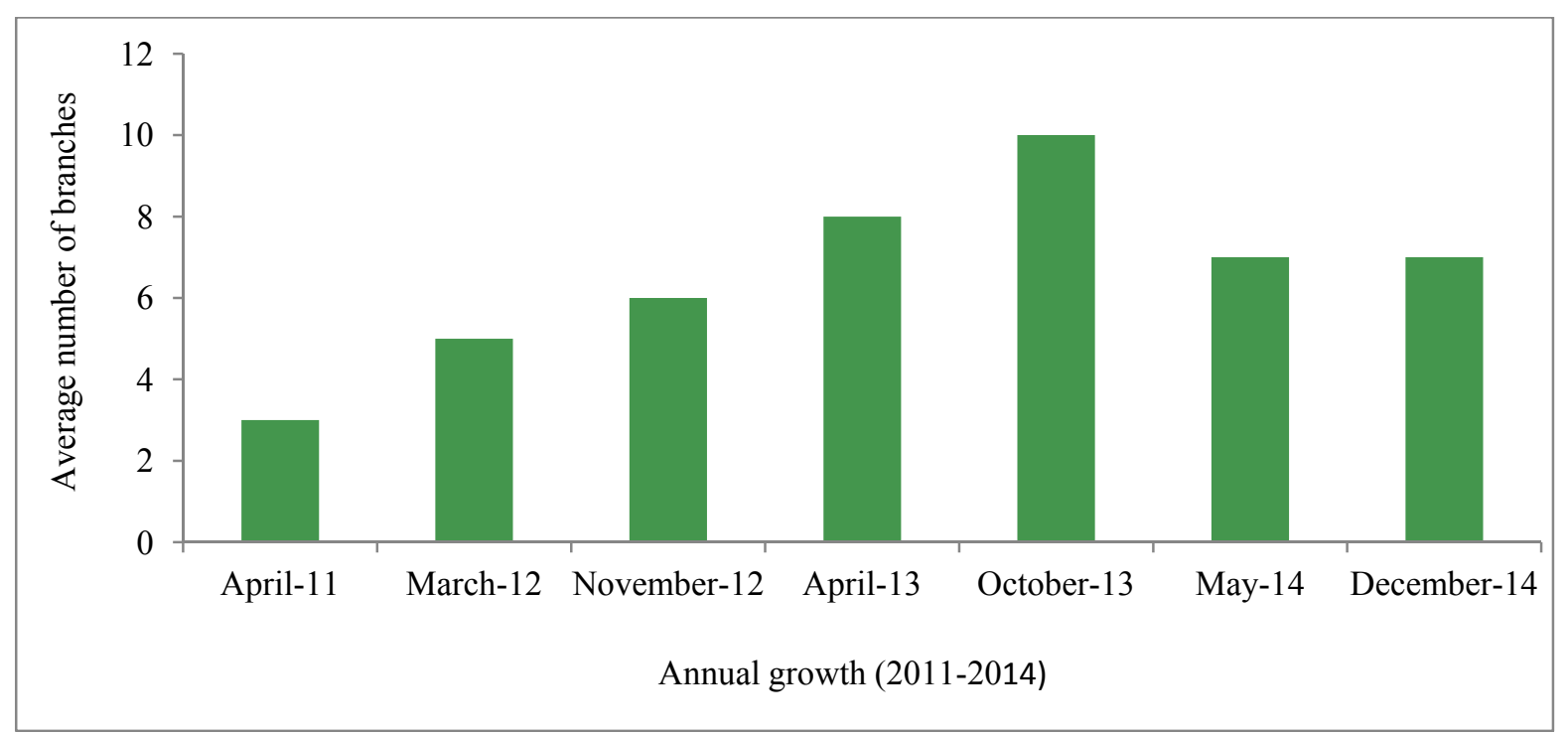

Fig. 4 The average number of branches of Lycium shawii for the period from 2011 to 2014.

A number of annual native plant species were observed at experimental sites as a result of deposition of seeds by wind action and new climate developed by introduced native shrub. Examples of native plants are Fagonia indica, Fagonia bruiguieri, Stipagrostis plumosa, Plantago coronopus, Plantago ciliata, Plantago boissieri, Rumex vesicarius, Savignya praviflora, Launaea mucronata, Picris babylonica and Diplotaxis harra. These plants have produced micro flora and fauna, where new birds, lizards and insects were noticed (Fig. 5).

Plant can effectively trap sand and form nabkha when their height reach $10-15 \mathrm{~cm}$. Lycium plant have the ability to form larger nabkha. It was effective in trapping sediment close to the ground surface, because it has the largest size of bush about $1.5 \mathrm{~m}$ and wider canopy more than $2 \mathrm{~m}$. The efficiency of the dominant plant species in trapping and preventing sand movement was measured by estimating the volume of trapped sand for each plant using the double semi-conical formula [9], as Eq. (1):

Volume of trapped sand $\left(\mathrm{m}^{3}\right)=1 / 6(W \times H \times L)(1)$ where, $W$ is the width of nabkhas; $H$ is the height of nabkhas; $L$ is length of nabkhas.

The average volume of mobile sand trapped by Lycium shawii was $1.2 \mathrm{~m}^{3}$ (Fig. 6). The trapped sand mounds around plant protect, conserve and feed the plant with water and nutrients. The wild fauna, such as wild rat and lizard, uses such sand body for shelter, source of food and nesting habitats.

The native plant Lycium was noticed to be the greatest native shrub appropriate for the initial revegetation program at Liyah refilled quarries through special care. Lycium plantlets showed $100 \%$ survival in the field condition due to following:

(1) The hill (experimental site) acts as wind breaks reduce wind speed;

(2) At the first year, the plantlets are irrigated with fresh water to reduce salinity of soil and to give opportunity to plantlets root to grow easily in hard soil;

(3) Addition of compost increases the organic content of the soil;

(4) Addition of peat moss and mulching with palm leaves maintain humidity;

(5) Irrigation the plantlets with regular drip-irrigation.

Lycium can be planted at any time from October to April except for the summer months. The number of annual plants in the pilot site increased yearly as a result of the microclimate development. Lycium shawii was selected in restoration for the following criteria:

(1) It can tolerate in harsh environmental conditions; 


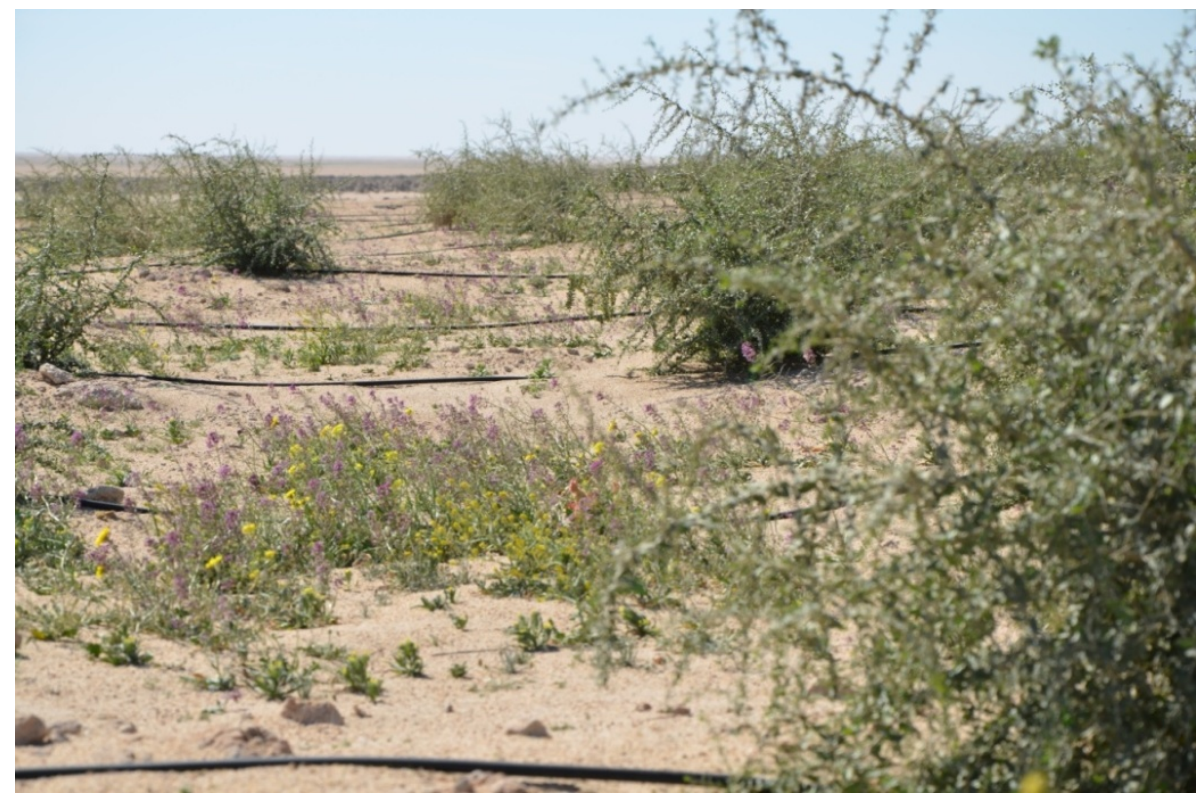

Fig. 5 Annual native plants introduce at the experimental site.

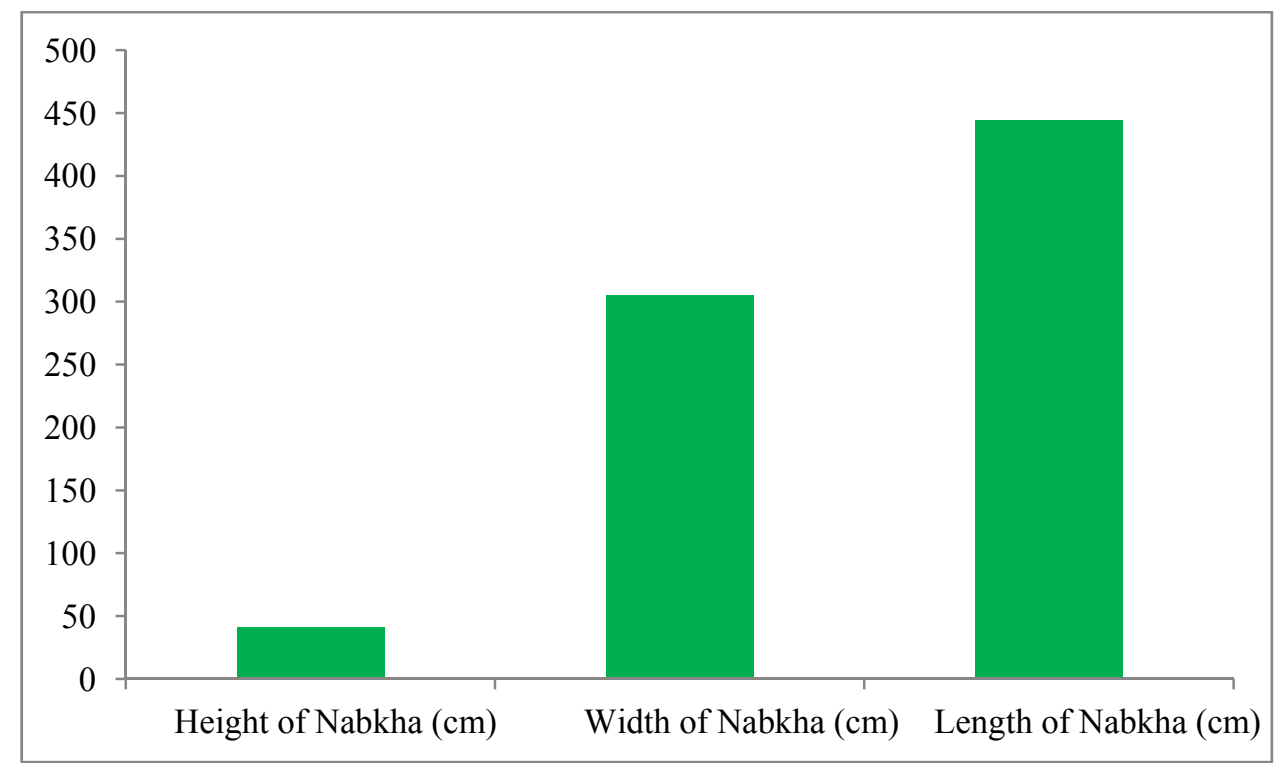

Fig. 6 The average morphometric parameters of Lycium shawii nabkhas (20 plants).

(2) It can grow in a nutrient poor soil;

(3) It has sweet globular fruits which are red to orange berries;

(4) It is likely to grow in the slightly alkaline soil having $\mathrm{pH}$ values from 7.2 to 7.4 , low carbonate content, low conductivity and low moisture content that matches with the natural physical and chemical characteristics of Liyah soil;

(5) It has long root system to absorb deep water;

(6) It has ability to form large desert nabkhas to trap mobile sand.

\section{Conclusions}

Kuwait is an arid land that faces serious problems in land degradation, therefore vegetation is especially important. Native plant production and reintroduction are very important for the desert rehabilitation programs. Successful restoration plans depends on the choice of plant species that are adapted to grow easily in degraded areas, resist dry arid condition and have a 

Thorny Shrub Lycium shawii

tap root system that can quickly reach the residual soil moisture. Lycium desert shrubs are example of native drought resistant plant that has socioeconomic, environmental and ecological criteria. Native plant Lycium was found to be the best native shrub suitable for the initial revegetation at Liyah. It can be planted at any time, except the summer months with special attention need to be undertaken for the field establishments during the planting season. It has special modification; it sheds their leaves during hot summer months and resprouts during September. Addition of compost enhances the plant growth, but not necessary. It is highly recommended to use rehabilitation programs in degraded soil.

The need for conserving the desert ecosystem and their components has become increasingly apparent. Accelerated development of the desert has subjected the fragile ecosystems to almost non-restorable condition. The establishment of protected areas (center for development of wild life habitats) at Liyah area potentially preserves the natural ecological systems of the national area; contribute positively to the region's ecological balance, scientific research and education, natural history preservation, recreational opportunities.

\section{References}

[1] Al-Hajraf, S., Al-Enezi, A., Al-Dousari, A. M., Brown, J., and Delima, E. 2008. Environmental Rehabilitation Study of Quarries on the State of Kuwait. EC006C, Final Report
KISR 9475, Kuwait Institute for Scientific Research, Kuwait.

[2] Society for Ecological Restoration (SER). 2016. "Native Plant Enhancement and Seed Based Restoration in Kuwait's Arid Environment." Society for Ecological Restoration (SER) News. Accessed June, 2016. https://c.ymcdn.com/sites/www.ser.org/resource/resmgr/P ublications/SERNews/30-3_SERNews_(2016).pdf.

[3] Zaman, S. 1997. "Effects of Rainfall and Grazing on Vegetation Yield and Cover of Two Arid Rangelands in Kuwait." Environmental Conservation 24 (4): 344-50.

[4] Omar, S., Al-Mutawa, Y., and Zaman, S. 2000. Vegetation of Kuwait. Kuwait: Al-Assriya Printing Press, Publishing and Distribution Company.

[5] Ahmed, M., and Al-Dousari, A. M. 2012. Rehabilitation of Degraded Playas of Kuwait by Using Water Harvesting Techniques. EC048G, Technical Report KISR11095, Kuwait Institute for Scientific Research, Kuwait.

[6] Al-Dousari, A. M., Sudhersan, S., and Uddin, S. 2011. "Environmental Rehabilitation Study of the Liyah Refilled Quarries: Phase II, Pilot Demonstration for Land Rehabilitation." Kuwait Institute for Scientific Research (KISR) Proposal No. KISR10600, KISR, Kuwait.

[7] Ahmed, M., and Al-Dousari, A. M. 2015. "Rehabilitation of Artificial Degraded Playa by Using Palm Mat and Water Conservation Techniques." Journal of Agricultural Science and Technology A 5 (2): 90-8.

[8] USDA-NRCS. 2004. Soil Survey Laboratory Methods Manual: Soil Survey Investigations. Report No. 42, Version 4.0, United States Department of Agriculture Natural Resources Conservation Service, Washington, DC.

[9] Al-Dousari, A. M., Ahmed, M., Al-Senafy, M., and Al-Mutairi, M. 2008. "Characteristics of Nabkhas in Relation to Dominant Perennial Plant Species in Kuwait." Kuwait Journal of Science and Engineering 35 (1): 129-50. 